\title{
Reciprocal Potential Oscillations across the Electrolytic Cells Connected in Series
}

\author{
Chetansing K. Rajput \\ Correspondence: Dr. Chetansing K. Rajput, M.B.B.S., T.N.M.C., Mumbai University, ACST, 306, Vikrikar Bhavan, \\ Nashik-422010, India. Tel: +91 07057521129. E-mail: chetansingkrajput@gmail.com
}

Received: November 21, 2015 Accepted: December 7, 2015 Online Published: December 10, 2015

doi:10.5539/ijc.v8n1p32

URL: http://dx.doi.org/10.5539/ijc.v8n1p32

\begin{abstract}
The series arrangement of identical electrolytic cells having copper anodes and chloride electrolyte is found to demonstrate an extremely asymmetric and reciprocally oscillating voltage drop across the series of these coupled cells. The origin of this phenomenon is attributed to the presence of different extents of cuprous oxide phase on surfaces of the anodes of different cells, in the series. Such series arrangement of multiple electrolytic cells introduces a novel phenomenon of the non-linear temporal behaviour of coupled cells. Most importantly, such configuration proves the very existence of adsorbed $\mathrm{Cu}_{2} \mathrm{O}$ on surface of copper anode, in acidic chloride media. And hence, it signifies the important role of $\mathrm{Cu}_{2} \mathrm{O}$ in the electro-dissolution mechanism of copper anode, even at lower $\mathrm{pH}$ values.
\end{abstract}

Keywords: reciprocal potential oscillations, copper anode, chloride electrolyte, potential oscillations, electrochemical oscillations

\section{Introduction}

Electro-dissolution of copper anode in acidic chloride media has always been the area of research interest of many investigators. As per general acceptance, the anodic dissolution of copper, in acidic chloride electrolyte, proceeds via formation of $\mathrm{CuCl}$ phase and soluble cuprous chloride complexes, like $\mathrm{CuCl}_{2}{ }^{-}, \mathrm{CuCl}_{3}{ }^{2-}$, etc. (Lee et al. 1986; Kear et al. 2004; Crundwell et al. 1992; Nobe et al. 1979). However, there are arguments regarding the formation of $\mathrm{Cu}_{2} \mathrm{O}$ phase in acidic environment. The potential-pH diagrams do not permit the presence of copper oxide in acidic chloride electrolyte. Also, according to previous studies, oxide is hard to form in the bulk electrolyte, at lower $\mathrm{pH}$ values (Tromans et al. 1991; Sourisseau et al. 2005).

However, this does not exclude the existence of $\mathrm{Cu}_{2} \mathrm{O}$ as an adsorbed layer on anodic surface. What happens in the thin surface film at electrode-electrolyte interface, where mass transport and electron transfer is limited to a small space, is a different scenario than what happens in bulk electrolyte.

This paper describes the phenomenon of potential oscillations between the electrolytic cells, connected in series. The rise in voltage across one of the coupled cells, is accompanied by the fall of voltages across other cells in the series. Hence, such kind of electrochemical oscillations can be termed as 'Reciprocal Potential Oscillations' (R.P.O.s), between the connected cells. Also, the amplitude of these R.P.O.s is found to show strong dependence upon $\mathrm{Cl}^{-}$concentration in electrolyte. Hence, this phenomenon can be successfully exploited for the detection of chloride ions and determination of their concentration in the electrolyte. This phenomenon can also be used to assemble an electrochemical clock, to demonstrate the exact aetiology and mechanism of the electrochemical oscillations, etc.

Also, the aim of present study is to reveal the mechanism of this new type of temporal behaviour in electrochemistry. The interpretation of its mechanism is presented on basis of the periodic formation and dissolution of the passivating cuprous oxide layer on anodic surface. The non-linear dynamics of $\mathrm{Cu}$ |Chloride system can be resolved with such series configuration of electrolytic cells. Also, such coupled cells enable the detection of adsorbed $\mathrm{Cu}_{2} \mathrm{O}$ in acidic environment, with usual characterization techniques.

\section{Experimental}

\subsection{Instrumentation}

The observed phenomenon of R.P.O.s can be demonstrated with the series arrangement of a couple of identical electrolytic cells, each cell having a copper anode, 1.01 millimeter in diameter and 55 millimetre long (minimum purity of copper $=99.9 \%$ ) and 100 millilitre of $0.5 \mathrm{M} \mathrm{HCl}$ (Fisher Scientific), as electrolyte. All solutions are prepared in double distilled water. 
A digital voltmeter is connected in parallel to each of the two electrolytic cells. A DC supply is used for external voltage application. (The phenomenon of RPOs can be well demonstrated with application of any smaller external voltage across the series of these cells. However, in these experiments, 30 volts DC is applied for getting the potential oscillations of larger amplitudes, which enable the clearer differentiation between the active and passive anodes.) All experiments are performed at $25^{\circ} \mathrm{C}$.

\subsection{Characterization}

Fourier transform infrared (FT-IR) spectroscopy, Scanning electron microscopy, Energy dispersive X-ray analysis and $\mathrm{X}$-Ray diffractometry are introduced for the characterization of anodic films. The FT-IR measurements are performed with Shimadzu IR Affinity spectrophotometer, over the range of 400-4000 $\mathrm{cm}^{-1}$. Scanning electron microscopy (SEM) measurements are carried out with FESEM ULTRA PLUS instrument by ZEISS Co. SEM - coupled energy dispersive $\mathrm{X}$-ray spectroscopy (EDS) is performed for elemental analysis. The XRD measurements are performed with PANalytical X'Pert Pro X Ray diffractometer, with $\mathrm{Cu}-\mathrm{K} \alpha$ radiation over angular range $10^{\circ} \leq 2 \theta \leq 90^{\circ}$, in 0.0167 step size $(\lambda=1.5418 \AA)$.

\section{Results and Discussion}

\subsection{Reciprocal Potential Oscillations}

Upon applying the voltage of 30 volts across the series of these electrolytic cells, the voltage across each of the two individual cells rises and falls, periodically and reciprocally, from as high as 29 volts to as low as 1 volt (i.e. the average amplitude of oscillations $=28 \mathrm{v}$ ), with frequency of about $1 / 240 \mathrm{~Hz}$, which signifies that the anode of each cell attains the similar state of activity / passivity after around every 240 seconds of electrolysis. The reciprocal potential oscillations between the coupled cells can be graphically represented, as shown in figure 1 .
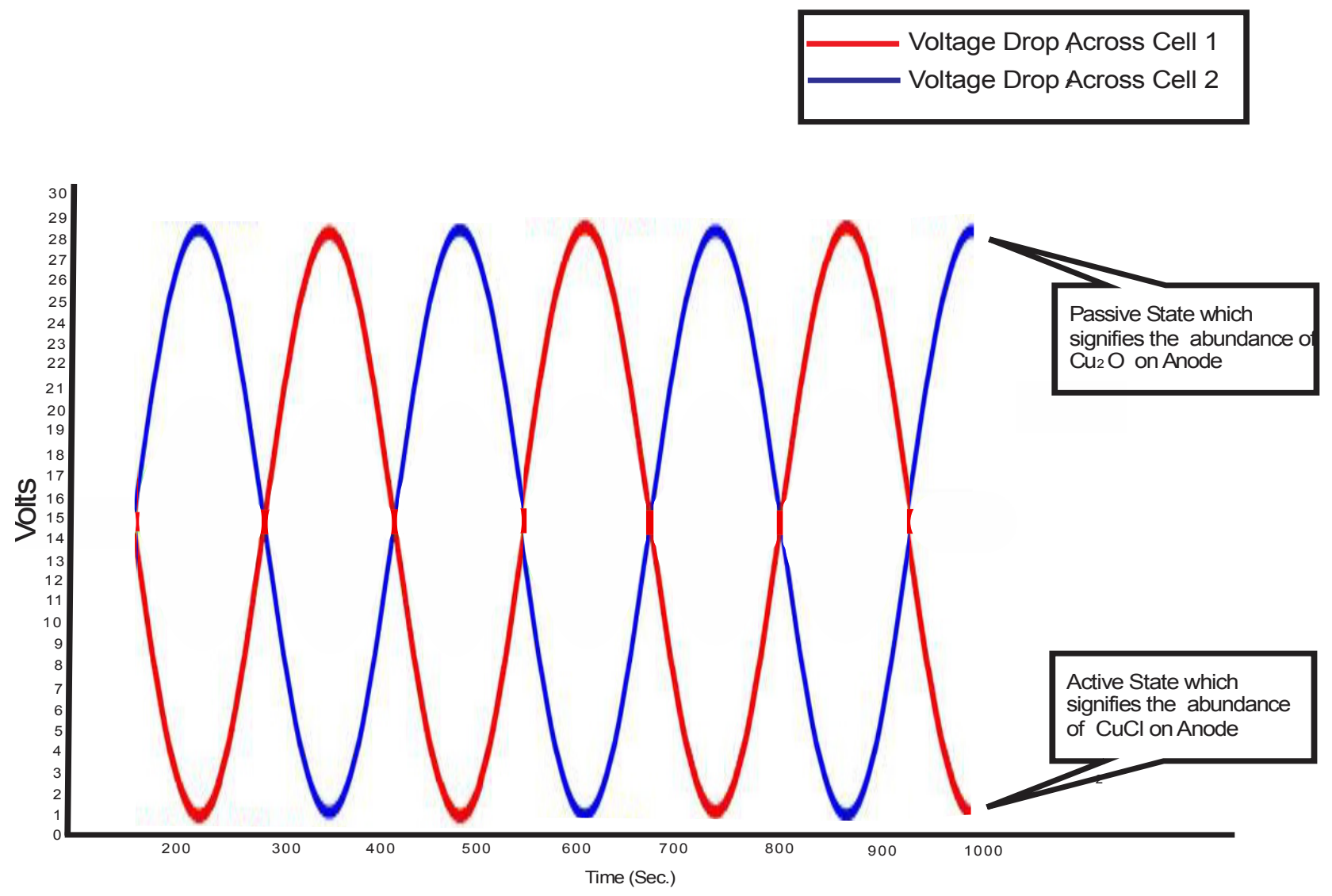

Figure 1.Chrono- Potentiograms of the two described cells, connected in series

\subsection{Electro-dissolution Mechanism and the Passivation of Copper Anode}

As per general acceptance, the electro-dissolution of copper anode in chloride media proceeds via following two steps reaction mechanism (Lee et al. 1986; Kear et al. 2004; Crundwell et al. 1992; Nobe et al. 1979).

Initial step is the adsorption of $\mathrm{Cl}^{-}$on $\mathrm{Cu}$ surface, followed by the formation of adsorbed $\mathrm{CuCl}$ by reaction (1) 


$$
\mathrm{Cu}+\mathrm{Cl}^{-} \rightarrow \mathrm{CuCl}+\mathrm{e}^{-}
$$

This $\mathrm{CuCl}$ film has poor adhesion to copper surface and in presence of $\mathrm{Cl}^{-}$ions, it is transformed into the soluble cuprous chloride complex.

$$
\mathrm{CuCl}+\mathrm{Cl}^{-} \rightarrow \mathrm{CuCl}_{2}^{-}
$$

It is also well known that, at higher concentration of $\mathrm{Cl}^{-}[\sim 1 \mathrm{~mol} \mathrm{~L}-1]$, the higher cuprous - chloride complexes are formed.

$$
\begin{aligned}
& \mathrm{CuCl}_{2}{ }^{-}+\mathrm{Cl}^{-} \rightarrow \mathrm{CuCl}_{3}{ }^{2-} \\
& \mathrm{CuCl}_{3}{ }^{2-}+\mathrm{Cl}^{-} \rightarrow \mathrm{CuCl}_{4}{ }^{3-}
\end{aligned}
$$

In neutral or alkaline $\mathrm{pH}$ media, at elevated concentration of dissolved $\mathrm{CuCl}^{2-}$ species, the equilibrium of following reaction (5) shifts to right, and cuprous oxide is precipitated by hydrolysis of $\mathrm{CuCl}^{2-}$ (Kear et al. 2004).

$$
2 \mathrm{CuCl}_{2}{ }^{-}+2 \mathrm{OH}^{-} \rightleftharpoons \mathrm{Cu}_{2} \mathrm{O}_{(\mathrm{s})}+\mathrm{H}_{2} \mathrm{O}+4 \mathrm{Cl}^{-}
$$

Moreover, cuprous oxide is also formed by the oxidation of anodic copper, through following reaction (6)

$$
2 \mathrm{Cu}+2 \mathrm{OH}^{-} \rightarrow \mathrm{Cu}_{2} \mathrm{O}_{(\mathrm{s})}+\mathrm{H}_{2} \mathrm{O}+2 \mathrm{e}^{-}
$$

There is consensus among the investigators, about the existence of $\mathrm{Cu}_{2} \mathrm{O}$ at neutral or alkaline $\mathrm{pH}$ values (Tromans et al. 1991). Cuprous oxide, formed by reaction (5) \& (6), is responsible for the passivation of copper anode. However, under continuous attack of aggressive $\mathrm{Cl}^{-}$ions, this passivating $\mathrm{Cu}_{2} \mathrm{O}$ layer is converted into $\mathrm{CuCl}$ phase, by reaction 7 .

$$
\mathrm{Cu}_{2} \mathrm{O}+2 \mathrm{Cl}^{-}+2 \mathrm{H}^{+} \rightleftharpoons 2 \mathrm{CuCl}+\mathrm{H}_{2} \mathrm{O}
$$

It is well known that, a single electrolytic cell, having copper anode in chloride media, exhibits very small current oscillations. Under potentiostatic conditions, a typical three electrodes cell, with copper as working electrode in chloride electrolyte, is long known to produce these tiny current fluctuations, which are generally attributed to the formation of the $\mathrm{CuCl}$ film on surface of anode (Lee et al. 1985; Basset et al. 1990).

However, such single cell is not found to produce obvious potential oscillations. Also, the role of $\mathrm{Cu}_{2} \mathrm{O}$ in the non-linear behaviour of $\mathrm{Cu}$ acidic chloride system has not been recognized yet, since the Pourbaix diagrams of $\mathrm{Cu}-\mathrm{Cl}-\mathrm{H}_{2} \mathrm{O}$ system do not permit the existence of $\mathrm{Cu}_{2} \mathrm{O}$ in acidic chloride media (Tromans et al. 1991), as shown in figure 2. And hence, the oxide formation by reactions (5), (6) and (7) is considered to be implausible, in acidic environment.

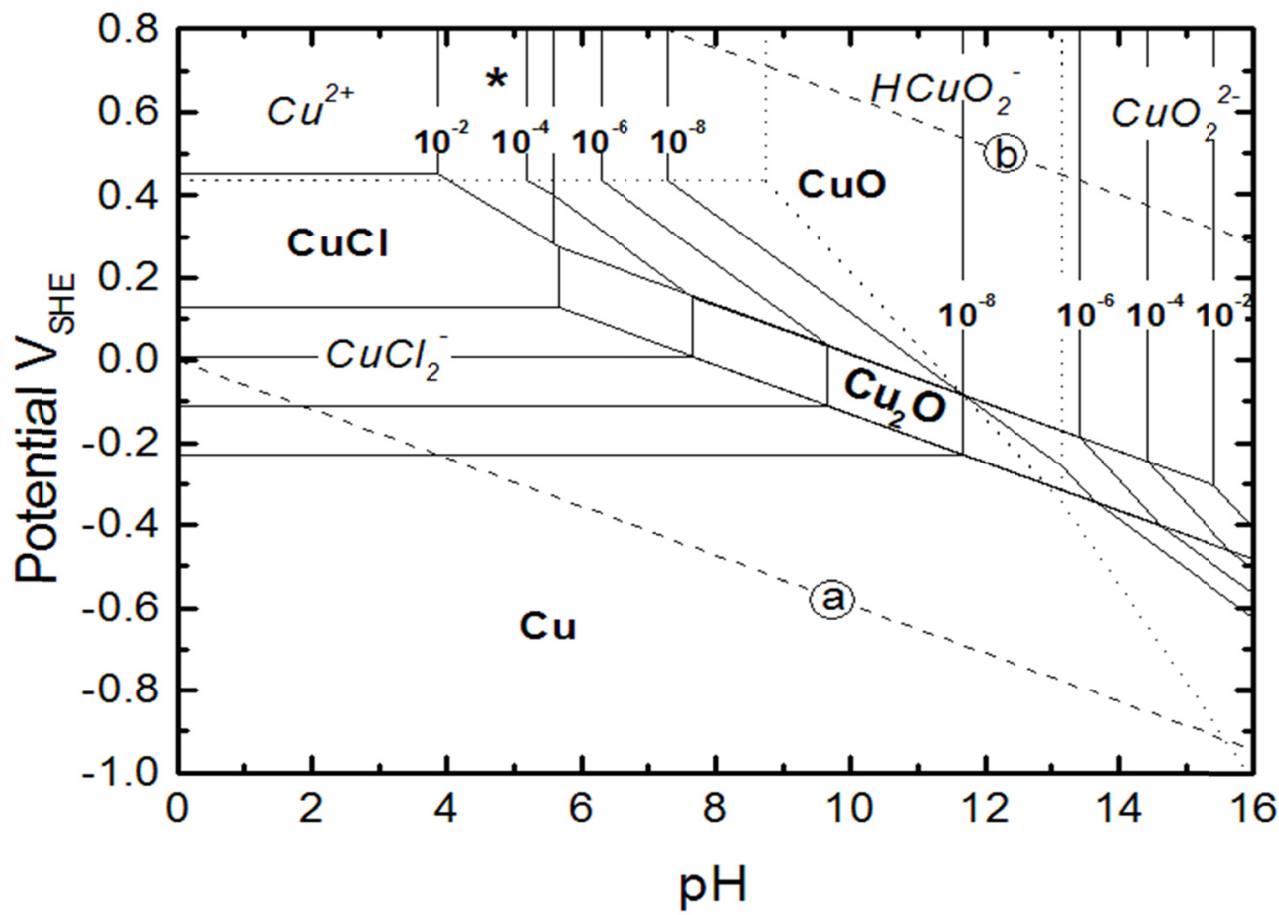

Figure 2. Potential-pH diagram for $\mathrm{Cu}-\mathrm{Cl}-\mathrm{H}_{2} \mathrm{O}$ system at $25^{\circ} \mathrm{C}$

\subsection{Origin and Mechanism of Reciprocal Potential Oscillations}

Now it has been observed that, if such multiple electrolytic cells having copper anode and acidic chloride electrolyte, are connected in series, the competitive adsorption of $\mathrm{Cl}^{-}$and $\mathrm{OH}^{-}$species on copper anodes, and subsequent formation 
of cuprous chloride $(\mathrm{CuCl})$ and cuprous oxide $\left(\mathrm{Cu}_{2} \mathrm{O}\right)$ accordingly, produce the interesting phenomenon of reciprocally oscillating voltage drop, across the series of these cells. Modestov et al had proposed that, in $0.5 \mathrm{M}$ chloride solution, at $\mathrm{pH} 8.5$ or higher, $\mathrm{Cu}_{2} \mathrm{O}$ is formed first, whereas, at $\mathrm{pH} 5.7$ and lower, $\mathrm{CuCl}$ is formed initially on copper surface, which is followed by $\mathrm{Cu}_{2} \mathrm{O}$ formation under the $\mathrm{CuCl}$ layer. (Modestov et al.1995).

Hence, the activity/passivity status of anode can be attributed to the relative extents of two anodic partial reactions viz. formation of porous $\mathrm{CuCl}$ film and formation of passivating $\mathrm{Cu}_{2} \mathrm{O}$ layer under the $\mathrm{CuCl}$ film. The formation of $\mathrm{Cu}_{2} \mathrm{O}$ passivates the copper anode and hinders copper dissolution as $\mathrm{CuCl}$ and $\mathrm{CuCl}_{2}{ }^{-}$, which results in the rise of potential difference across the cell. $\mathrm{Cu}_{2} \mathrm{O}$ layer is clearly protective and passivating in nature, since the current falls significantly following $\mathrm{Cu}_{2} \mathrm{O}$ film formation. Hence, it commences the trans-passive dissolution of copper anode, possibly as $\mathrm{Cu}^{++}$ species. However, this $\mathrm{Cu}_{2} \mathrm{O}$ layer is under continuous attack of aggressive $\mathrm{Cl}^{-}$anions and the stability of $\mathrm{Cu}_{2} \mathrm{O}$ is inversely proportional to the concentration of chloride ions (Bianchi et al 1978). The aggressiveness of $\mathrm{Cl}^{-}$causes the localized breakdown of this oxide film and pitting commences by nucleation of precipitated $\mathrm{CuCl}$ at week points in this underlying $\mathrm{Cu}_{2} \mathrm{O}$ film. This causes the thinning of $\mathrm{Cu}_{2} \mathrm{O}$ layer, by formation of the outer porous layer rich in chloride species and finally the dissolution of $\mathrm{Cu}_{2} \mathrm{O}$ layer from copper anode, in form of copper chloride complex (reaction 5)/cuprous chloride salt film (reaction 7). The attack of aggressive chloride ions replaces $\mathrm{Cu}_{2} \mathrm{O}$ in the passivating layer, forming $\mathrm{CuCl}$ phase by reaction (7). This poorly adherent, porous $\mathrm{CuCl}$ film permits the diffusion of $\mathrm{Cl}^{-}$ions, and hence, the generalized active dissolution of copper anode, by reactions (1) \& (2), commences. It leads to the transition of copper anode to active state i.e. low voltage state, which is indicated by the fall of voltage drop across that cell.

This mechanism of R.P.O.s can be schematically represented, as shown here in figure 3 .
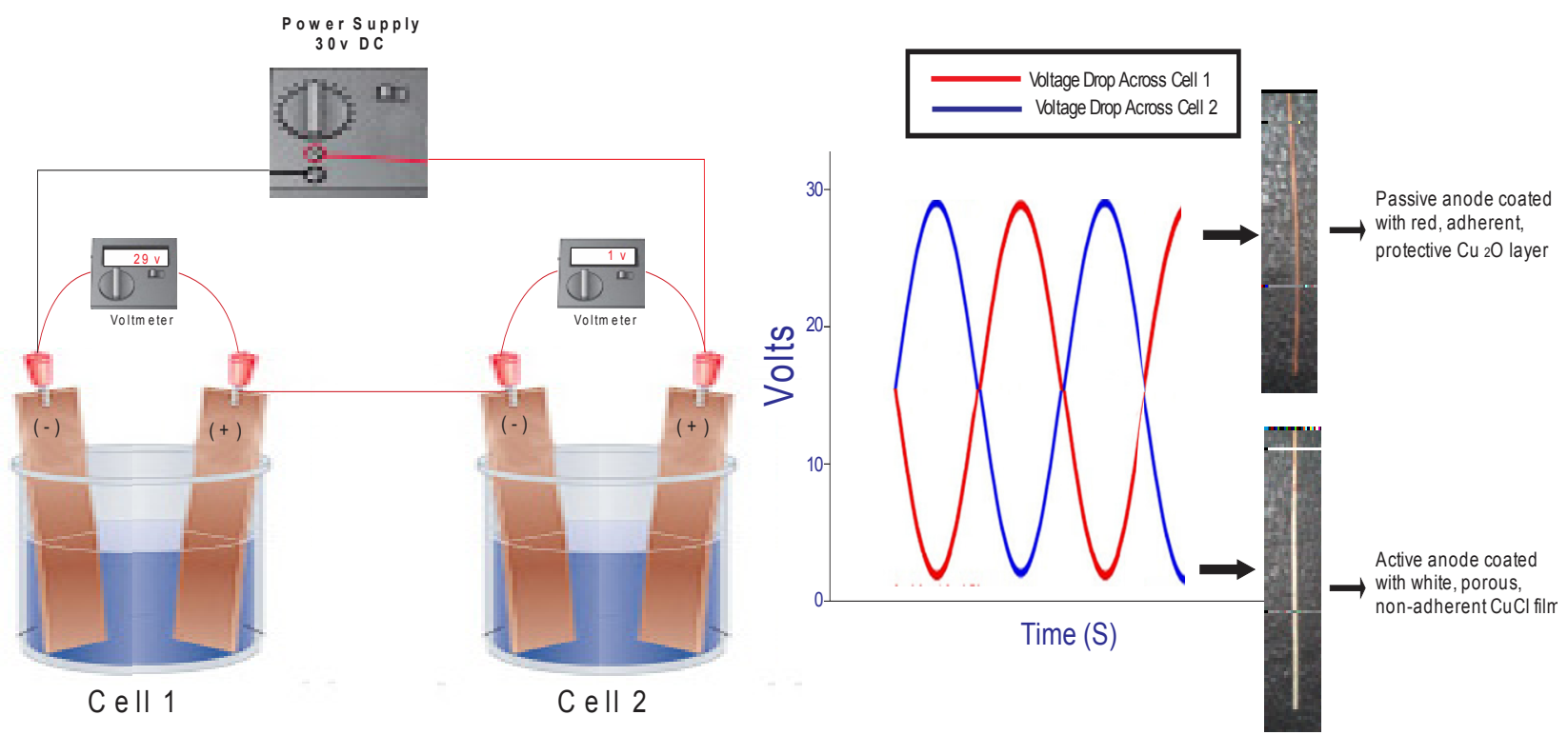

Figure 3. Schematic representation of the mechanism of Reciprocal Potential Oscillations

Thus, at any given time, the relative extent of $\mathrm{Cu}_{2} \mathrm{O}$ phase, adsorbed on anodic surface, decides the passivity / activity status of that anode, which in turn, determines the voltage drop across that particular electrolytic cell. The potential oscillations across the coupled cells accompany the dynamic film processes and the changing $\mathrm{Cu}_{2} \mathrm{O}: \mathrm{CuCl}$ ratios on the anodes. The active-passive transitions of anodes in the different cells in series are synchronized to produce an integrated and harmonious pattern, which manifests as the R.P.O.s between the coupled cells. Hence, such series arrangement of electrolytic cells clearly differentiates between the anodes in active and passive states, and also enables the detection of $\mathrm{Cu} 2 \mathrm{O}$ on passive anodic surface, in acidic chloride media.

\subsection{Characterization of Anodic Films}

FT-IR, SEM, EDS and XRD measurements are introduced for characterization of the anodic films, during active and passive states. The SEM images of anodic surfaces, and the chemical composition of anodic films revealed by EDS spectra signify the presence of cuprous oxide on anodic surface during passive state, while only cuprous chloride is detected during the active state of anode, as shown here, in figure 4. 
(a)
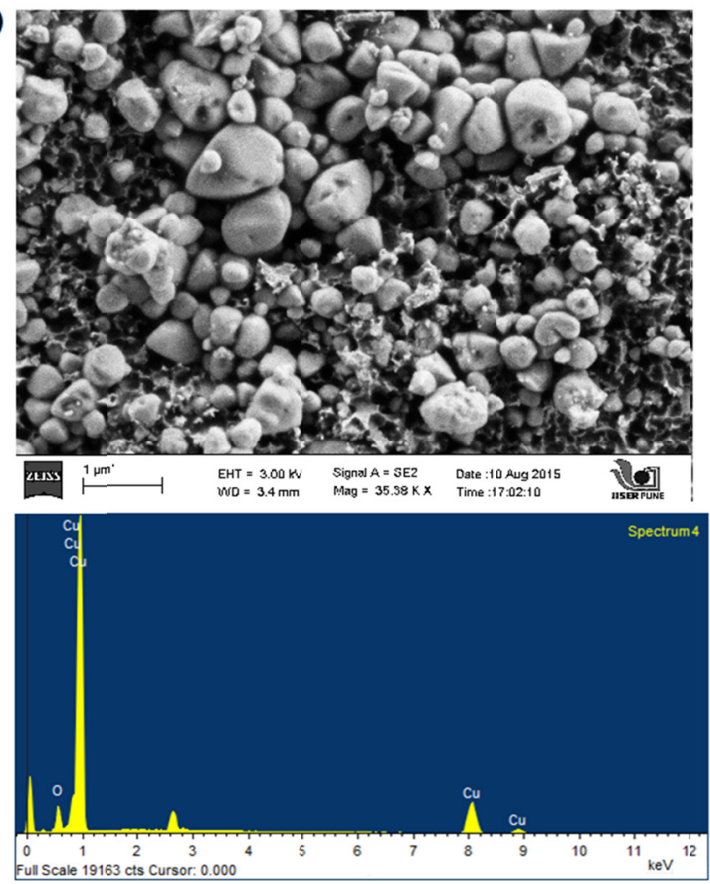

(b)
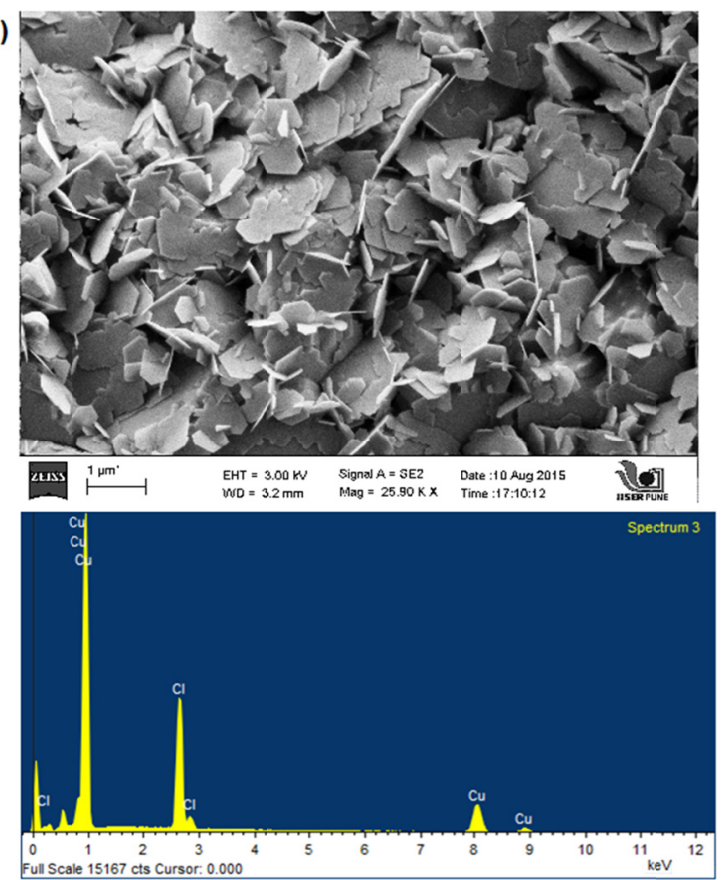

Figure 4. SEM micrographs and EDS spectra of the anodic films during (a) passive, and (b) active state

FT-IR spectrum is recorded over the range of $400-4000 \mathrm{~cm}^{-1}$. The FT-IR spectrum of the passivating layer on anodic surface, during high voltage state, indicates the presence of $\mathrm{Cu}_{2} \mathrm{O}$. The peak at $654.86 \mathrm{~cm}^{-1}$ corresponds to the vibrational mode of $\mathrm{Cu}-\mathrm{O}$ functional group in $\mathrm{Cu}_{2} \mathrm{O}$ phase.

Also, the XRD measurements, during the passive state of anode, reveal the presence of $\mathrm{Cu}_{2} \mathrm{O}$ on anodic surface. The characteristic $\mathrm{Cu}_{2} \mathrm{O}$ peak centred at $2 \theta$ of $36.49^{\circ}$ is observed and it corresponds to the lattice planes (111) of $\mathrm{Cu}_{2} \mathrm{O}$. This peak for $\mathrm{Cu} 2 \mathrm{O}$ is consistent with the JCPDS - PDF File No. 05-0667.

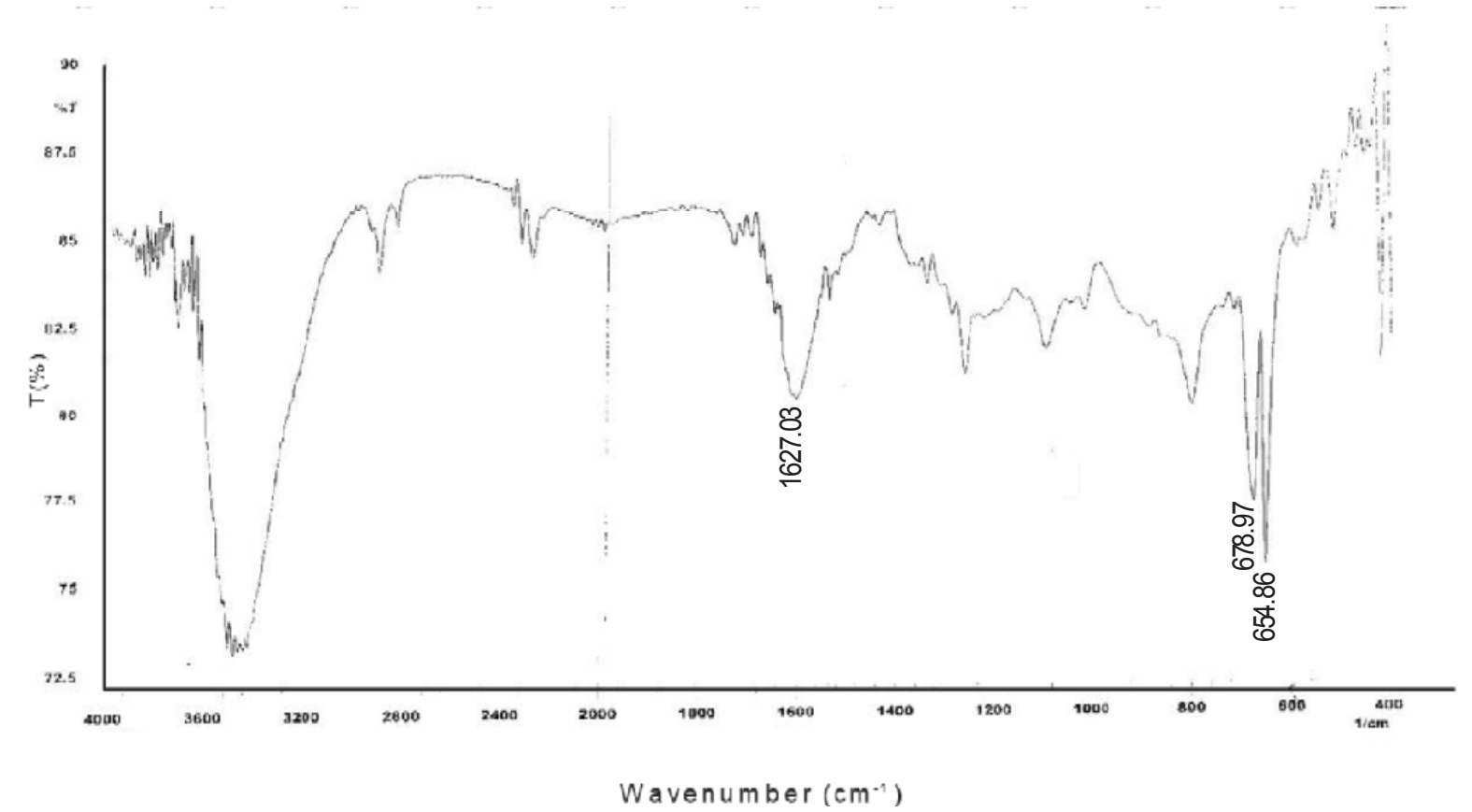

Figure 5.The FT-IR Spectrum of the passivating layer on anode, during high voltage state 


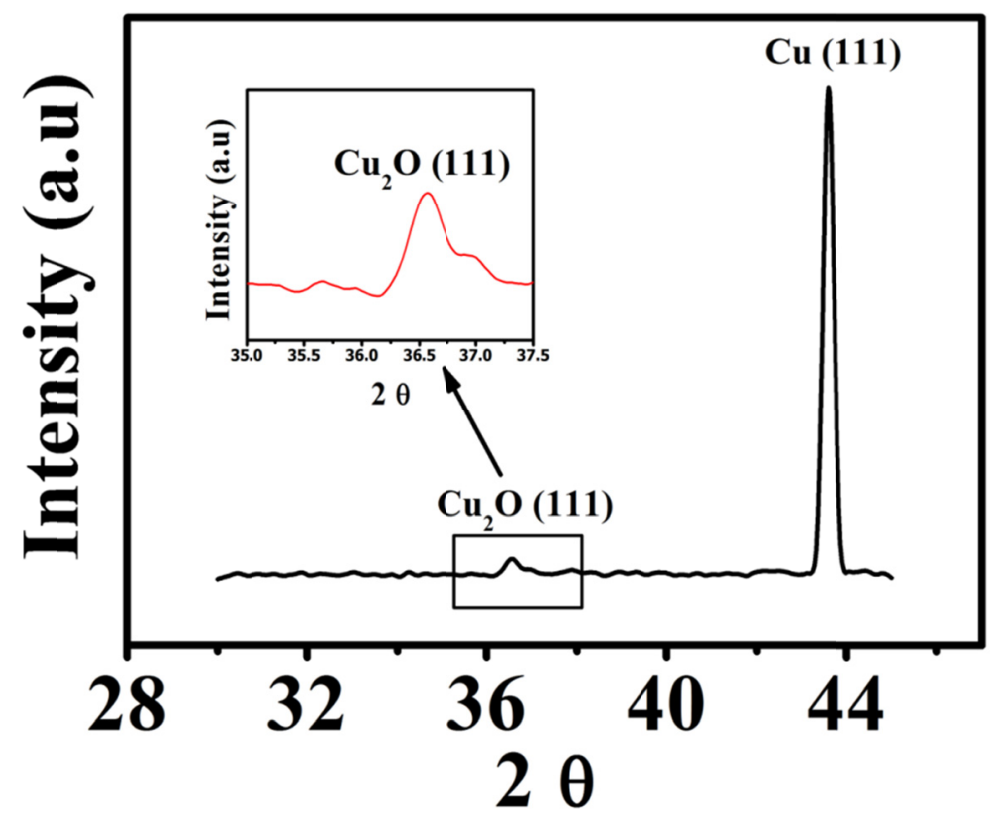

Figure 6. The XRD patterns of the anodic surfaces during the passive state

These results indicate the role of $\mathrm{Cu}_{2} \mathrm{O}$ in passivation of copper anode, even in acidic electrolyte. And hence, it signifies that, the periodic formation and dissolution of cuprous oxide layer on anodic surface is responsible for the non-linear temporal behaviour of $\mathrm{Cu}$ | chloride system.

\subsection{Influence of Chloride Ions Concentration on the Amplitude of R.P.O.s}

The amplitude of these RPOs is found to show strong dependence upon the $\mathrm{Cl}^{-}$concentration in electrolyte. At about 0.5 $\mathrm{M}$ concentration of $\mathrm{HCl}$ electrolyte, the coupled cells demonstrate R.P.O.s of maximum range $(1 \mathrm{v}$ to $29 \mathrm{v})$ and maximum amplitude $(28 \mathrm{v})$. The range and amplitude of R.P.O.s are found to be sequentially decreasing with higher as well as lower concentrations of $\mathrm{HCl}$, as shown in figure 7.

(a)

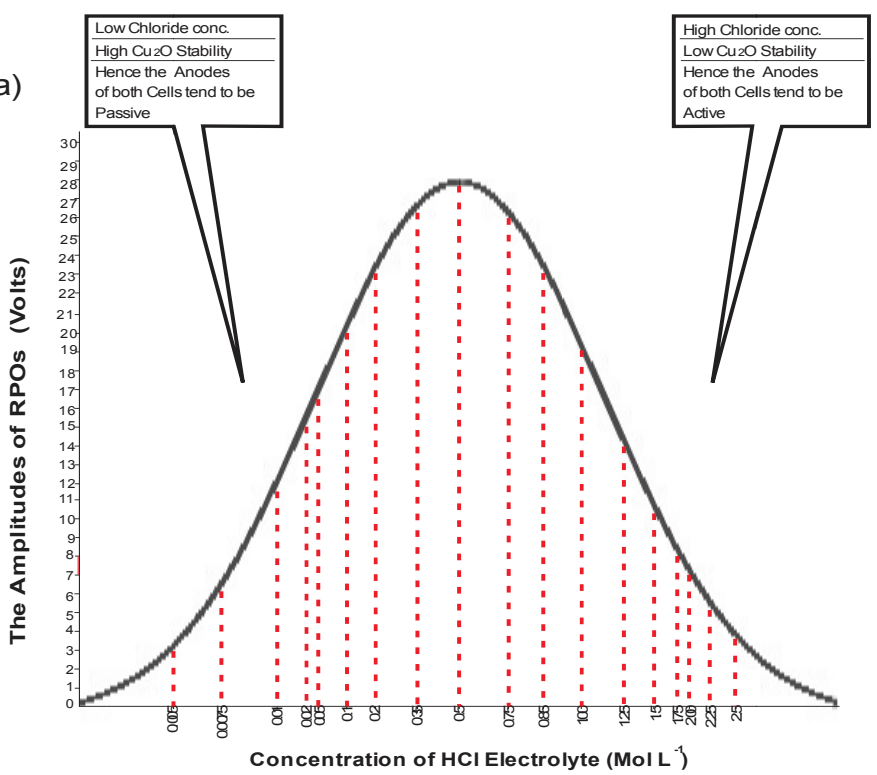

(b)

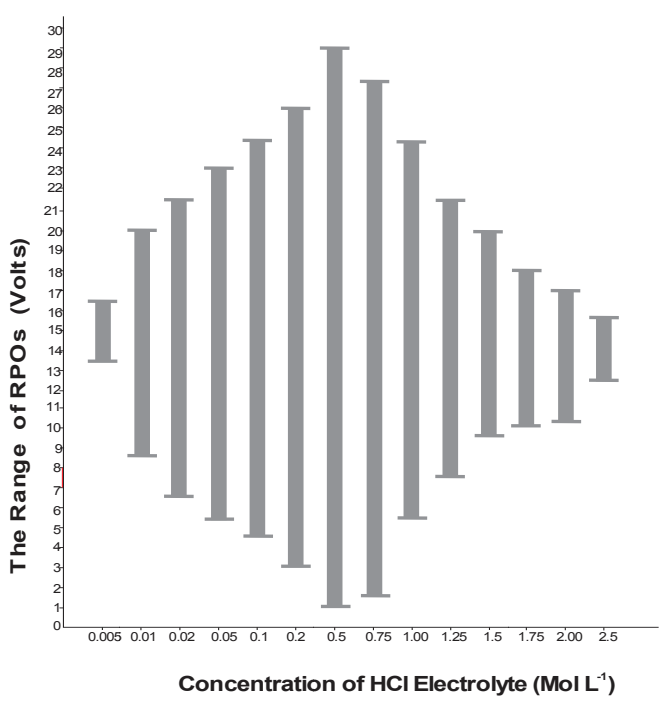

Figure 7.The Normal Distribution Curve showing variations in (a) The Average Amplitude and (b) The Average Range of R.P.O.s, in the described cells, during 600 seconds of electrolysis, with various concentrations of $\mathrm{HCl}$ electrolyte The dependence of the amplitude of RPOs on $\mathrm{Cl}^{-}$concentration can be explained on basis of the varying stability of $\mathrm{Cu}_{2} \mathrm{O}$ at different $\mathrm{Cl}^{-}$concentrations. At very low concentration of aggressive chloride anions, the stability of passivating cuprous oxide layer is very high. The deficient chloride concentration is incapable of the substantial 
dissolution of oxide from anode surface. Hence, the anodes of both the coupled cells tend to be passive. With increasing $\mathrm{Cl}^{-}$concentration in electrolyte, an equilibrium is established between the formation of passivating $\mathrm{Cu}_{2} \mathrm{O}$ layer and its leaching from the anodic surface, in form of copper (I) chloride salt film / soluble cuprous chloride complexes. At such optimum concentration $(\approx 0.5 \mathrm{MHCl})$, the cells connected in series demonstrate the voltage asymmetry and R.P.O.s at maximum amplitude. However, with $\mathrm{HCl}$ concentration higher than $0.5 \mathrm{M}$ and so, the anodes cannot sustain passivity, since the abundance of aggressive chloride anions diminish the stability of $\mathrm{Cu}_{2} \mathrm{O}$ layer, which is now incapable of passivating the anodes up to optimum level. Both the anodes tend to be active and hence, amplitude of R.P.O.s is found to be decreasing again, with increasing concentration of $\mathrm{Cl}^{-}$. The dependence of amplitude of R.P.O.s on $\mathrm{Cl}^{-}$ concentration gives a typical bell shaped curve, as shown in figure 7(a). Hence, this phenomenon can be successfully exploited for the detection of chloride ions and determination of their concentration in the electrolyte.

Aqueous solutions of all chloride electrolytes, including $\mathrm{KCl}, \mathrm{NaCl}, \mathrm{CuCl}_{2}$, etc. demonstrate this effect, very well. Most importantly, this effect is well demonstrated by $\mathrm{HCl}$ electrolyte, with the concentrations ranging from $\sim 0.005 \mathrm{M}$ to $\sim 2.5 \mathrm{M}$. Thus, contrary to common belief and potential- $\mathrm{pH}$ diagrams for $\mathrm{Cu}$-acidic chloride electrolytic system, this phenomenon of R.P.O.s, observed with $\mathrm{HCl}$ electrolyte signifies the very existence of adsorbed $\mathrm{Cu}_{2} \mathrm{O}$ on copper anode, in acidic chloride media. $\mathrm{Cu}_{2} \mathrm{O}$ formation in acidic environment can be explained on basis of local $\mathrm{pH}$ changes. Copper cation abundance causes the electro-migration of $\mathrm{H}^{+}$ions from vicinity of anode to bulk solution, resulting in the rise of local $\mathrm{pH}$, which facilitates the formation of $\mathrm{Cu}_{2} \mathrm{O}$ on anodic surface.

Lastly, it has also been observed that the occurrence of R.P.O.s is independent of the composition of cathode and catholyte. The cathode composed of any metal is not found to affect the occurrence of this phenomenon. Also, if salt-bridges are introduced to separate the anolyte and the catholyte, it is observed that the occurrence of R.P.O.s is not affected by the constitution of catholyte.

\section{Conclusions}

Two identical electrolytic cells with copper anodes and certain concentrations of $\mathrm{HCl}$ electrolyte were connected in series and the voltages across the individual cells were plotted against time. This work demonstrated an extremely asymmetric voltage drop and reciprocal potential oscillations between the two coupled cells. SEM-EDS, FT-IR spectroscopy and XRD measurements are introduced for characterization of the anodic films. The characterization data revealed the presence of cuprous oxide on anodic surface, remarkably only during the passive state of anode. Hence, the origin of these R.P.O.s is attributed to the presence of different extents $\mathrm{Cu}_{2} \mathrm{O}$ phase, on surfaces of the anodes of different cells in series. Also, the amplitude of R.P.O.s is found to show strong dependence upon $\mathrm{Cl}^{-}$concentration in electrolyte. Most importantly, such series configuration of electrolytic cells enabled to prove the very existence of $\mathrm{Cu}_{2} \mathrm{O}$, adsorbed on the surface of the passive copper anode, in acidic chloride electrolyte. And hence, this work signified the important role of $\mathrm{Cu}_{2} \mathrm{O}$, in both, the electro-dissolution of copper anode in acidic chloride media, and the non-linear temporal behaviour of the $\mathrm{Cu} \mid$ chloride system.

\section{References}

Basset M. R., \& Hudson J. L. (1990). The Oscillatory Electro dissolution of Copper in Acidic Chloride Solution. $\begin{array}{lllll}\text { Journal of the Electrochemical } & \text { Society, } & 137(6), & 1815-1826 .\end{array}$ http://cat.inist.fr/?aModele $=$ afficheN\&cpsidt $=19260778$

Bianchi, G., Fiori, G., Longhi, P., \& Mazza, F. (1978). Horse Shoe Corrosion of copper alloys in flowing sea water: mechanism and possibility of cathodic of condenser tubes in power stations. Corrosion-NACE, 34, 396-406.

Crundwell, F. K. (1992). The anodic dissolution of copper in hydrochloric acid solutions. Electrochimica Acta, 37(15), 2707-2714. http://www.sciencedirect.com/science/article/pii/001346869285197S

Kear, G., Barker, B. D., \& Wlash, F. C. (2004). Electrochemical corrosion of unalloyed copper in chloride media-A critical review. Corrosion Science, 46, 109. http://www.sciencedirect.com/science/article/pii/S0010938X02002573

Lee, H. P., \& Nobe, K. (1986). Kinetics and Mechanisms of Cu Electro dissolution in Chloride Media. Journal of The Electrochemical Society, 133(10), 2035-2043. http://m.jes.ecsdl.org/content/133/10/2035.abstract

Lee, H. P., Nobe, K., \& Pearlstein, A. J. (1985). Film Formation and Current Oscillations in the Electro dissolution of $\mathrm{Cu}$ in Acidic Chloride Media. Journal of the Electrochemical Society, 132(5), 1031. http://m.jes.ecsdl.org/

Modestov, A. D., Zhou, G. D., Ge, H. H., \& Loo, B. H. (1995). A study by voltammetry and photocurrent response method of copper electrode behaviour in acidic and alkaline solutions containing chloride ions. Journal of Electroanalytical Chemistry, 380, 63. http://www.sciencedirect.com/science/article/pii/002207289403577P

Nobe, K., \& Braun, M. (1979). Electro dissolution Kinetics of Copper in Acidic Chloride Solutions. Journal of the Electrochemical Society, 126(10), 1666. http://m.jes.ecsdl.org/ 
Sourisseau, T., Chauveau, E., \& Baroux, B. (2005). Mechanism of copper action on pitting phenomena observed on stainless steels in chloride media. Corrosion Science, l47(5), 1097-1117. http://www.sciencedirect.com/science/article/pii/S0010938X04001179

Tromans, D., \& Sun, R. H. (1991). Anodic Polarization Behaviour of Copper in Aqueous Chloride/Benzotriazole Solutions. Journal of the Electrochemical Society, 138(11), 3235-3244. http://m.jes.ecsdl.org/content/138/11/3235.abstract

\section{Copyrights}

Copyright for this article is retained by the author(s), with first publication rights granted to the journal.

This is an open-access article distributed under the terms and conditions of the Creative Commons Attribution license (http://creativecommons.org/licenses/by/3.0/). 